\title{
PEMBELAJARAN BERBASIS MASALAH UNTUK MENINGKATKAN KEMAMPUAN KOMUNIKASI MATEMATIK SISWA SEKOLAH MENENGAH PERTAMA
}

\author{
Oleh: Drs. Deddy Sofyan, M.Pd.
}

\begin{abstract}
Abstrak
Tujuan penelitian ini adalah untuk menelaah model pembelajaran yang lebih baik dalam meningkatkan kemampuan komunikasi matematik pada kelompok siswa yang mengikuti pembelajaran berbasis masalah terbuka, pembelajaran berbasis masalah terstruktur, dan pembelajaran konvensional. Penelitian ini merupakan studi eksperimen berbentuk kelompok kontrol pretes-postes. Populasi Penelitian ini adalah Siswa SMP Negeri di kabupaten Garut yang termasuk kategori sekolah kelompok tinggi. Sampel penelitian ini adalah siswa kelas VIII salah satu SMP Negeri di kabupaten Garut. Hasil yang diperoleh adalah kemampuan komunikasi matematik siswa yang mengikuti pembelajaran berbasis masalah terbuka sama baiknya dengan siswa yang mengikuti pembelajaran konvensional. Kemampuan komunikasi matematik siswa yang mengikuti pembelajaran berbasis masalah terbuka dan pembelajaran konvensional lebih baik daripada siswa yang mengikuti pembelajaran berbasis masalah terstruktur.
\end{abstract}

\section{Pendahuluan}

\section{Latar Belakang Masalah}

Pusat kurikulum, Balitbang Depdiknas (2003:3) menyatakan bahwa mata pelajaran matematika menumbuhkembangkan kemampuan menalar, yaitu berpikir sistematis, logis, dan kritis, dalam mengkomunikasikan gagasan atau dalam pemecahan masalah. Menurut Mulyasa (2003:21) acuan kurikulum berbasis kompetensi menjadikan sosok manusia Indonesia dalam jenjang pendidikan menengah salah satunya adalah memiliki kemampuan berkomunikasi. Kemampuan komunikasi matematik perlu menjadi fokus perhatian dalam pembelajaran matematika, sebab melalui komunikasi, siswa dapat mengorganisasi dan mengkonsolidasi berpikir matematikanya (NCTM, 2000a) dan siswa dapat mengeksplorasi ide-ide matematika (NCTM, 2000b). Oleh karena itu berdasarkan Pugalee (2001), siswa perlu dibiasakan dalam pembelajaran untuk memberikan argumen setiap jawabannya serta memberikan tanggapan atas jawaban yang diberikan oleh orang lain, sehingga apa yang sedang dipelajari menjadi bermakna baginya. Hal ini berarti guru harus berusaha untuk mendorong siswanya agar mampu untuk berkomunikasi.

Dalam kurikulum 2004 (Depdiknas, 2003:8) dinyatakan bahwa siswa setelah pembelajaran harus memiliki seperangkat kompetensi matematika yang harus ditunjukan pada hasil belajarnya dalam mata pelajaran matematika (standar kompetensi). Adapun kecakapan atau kemahiran matematika yang diharapkan dapat tercapai dalam belajar matematika mulai dari SD dan MI sampai SMA dan MA, adalah sebagai berikut:

1. Menunjukkan pemahaman konsep matematika yang dipelajari, menjelaskan keterkaitan antar konsep atau algoritma, secara luwes, akurat, efisien, dan tepat, dalam pemecahan masalah.

2. Memiliki kemampuan mengkomunikasikan gagasan dengan symbol, tabel grafik atau diagram untuk memperjelas keadaan atau masalah. 
3. Menggunakan penalaran pada pola, sifat atau melakukan manipulasi matematika dalam membuat generalisasi, menyusun bukti, atau menjelaskan gagasan dan pernyataan matematika.

4. Menunjukkan kemampuan strategik dalam membuat (merumuskan), menafsirkan, dan menyelesaikan model matematika dalam pemecahan masalah.

5. Memiliki sikap menghargai kegunaan matematika dalam kehidupan.

Kenyataan di lapangan menunjukkan bahwa hasil pembelajaran matematika dalam aspek komunikasi matematik masih rendah. Rendahnya kemampuan komunikasi matematik ditunjukkan dalam studi Rohaeti (2003) bahwa rata-rata kemampuan komunikasi matematik siswa berada dalam kualifikasi kurang. Demikian juga menurut Purniati (2003) menyebutkan bahwa respon siswa terhadap soal-soal komunikasi matematik umumnya kurang. Hal ini dikarenakan soal-soal komunikasi matematik masih merupakan hal yang baru, sehingga siswa mengalami kesulitan dalam menyelesaikannya.

Rendahnya kemampuan komunikasi matematik siswa akan mempengaruhi kualitas belajar siswa yang berdampak pada rendahnya prestasi belajar siswa di sekolah. Salah satu upaya yang dapat dilakukan dalam menyikapinya adalah pemilihan model pembelajaran yang tepat. Menurut Ruseffendi (1988:18) salah satu kemampuan yang harus dimiliki guru matematika sekolah menengah adalah mampu mendemonstrasikan dalam penerapan macam-macam metode dan tenik mengajar dalam bidang studi yang diajarkan.

Berdasarkan hal tersebut, maka perlu diterapkan suatu model pembelajaran yang dapat meningkatkan komunikasi. Salah satu model pembelajaran yang dapat merangsang berpikir tingkat tinggi dalam situasi berorientasi berbasis masalah termasuk belajar bagaimana belajar, dan dapat mengembangkan lingkungan kelas yang memungkinkan terjadinya pertukaran ide secara terbuka adalah Pembelajaran Berbasis Masalah (PBM). PBM memungkinkan dapat meningkatkan aktivitas siswa dalam komunikasi matematik.

PBM merupakan suatu strategi yang dimulai dengan menghadapkan siswa pada masalah keseharian yang nyata (authentic) atau masalah yang disimulasikan, sehingga siswa dituntut untuk berfikir kritis dan menempatkan siswa sebagai problem solver, menurut Riedesel (1990) komunikasi matematik berkaitan erat dengan kemampuan pemecahan masalah, sebab dalam mengungkapkan suatu masalah dapat dilakukan, dengan jawaban terbuka, masalah dinyatakan dengan cara lisan, masalah non verbal, menggunakan diagram, grafik dan gambar, mengangkat masalah yang tidak menggunakan bilangan, menggunakan analogi dan menggunakan perumusan masalah siswa. Dengan demikian melalui PBM siswa melakukan aktivitas komunikasi matematik, karena aktivitas komunikasi matematik dilakukan secara bersamaan dengan aktivitas pemecahan masalah. Sehingga, melalui PBM memungkinkan menumbuhkembangkan kemampuan siswa dalam komunikasi matematik.

Masalah yang dapat digunakan dalam PBM adalah dua tipe masalah, yaitu masalah terbuka (open-ended problem) atau disebut juga masalah tidak lengkap (ill-structured problem) dan masalah terstruktur (well-structured problem). Dalam masalah terstruktur, untuk menjawab masalah yang diberikan, siswa dihadapkan dengan submasalahsubmasalah sebagai pemandu untuk dapat menjawab masalah secara utuh. Dengan diberikannya submasalah-submasalah seperti ini, diharapkan siswa dapat belajar lebih mandiri sehingga diperkirakan memerlukan intervensi guru yang minimal. Sedangkan dalam masalah terbuka, siswa dihadapkan dengan masalah yang menuntutnya berpikir variatif dan fleksibel, karena masalah yang dihadapinya memiliki banyak alternatif cara penyelesaian dengan jawaban tunggal atau memiliki banyak 
alternatif cara penyelesaian dengan multi jawaban yang benar. Masalah terbuka, lebih menarik dan menantang bagi siswa.

Berdasarkan hal di atas, maka penulis tertarik untuk meneliti tentang "Pembelajaran Berbasis Masalah untuk Meningkatkan Kemampuan Komunikasi Matematik Siswa Sekolah Menengah Pertama (SMP)".

\section{Rumusan Masalah}

Masalah penelitian ini adalah: Kemampuan komunikasi manakah yang lebih baik yang dicapai siswa yang mengikuti pembelajaran berbasis masalah terbuka, pembelajaran berbasis masalah terstruktur, dan pembelajaran konvensional.

\section{Tujuan Penelitian}

Tujuan penelitian ini adalah: Menelaah model pembelajaran yang lebih baik dalam meningkatkan kemampuan komunikasi matematik.

\section{Hipotesis Penelitian}

Hipotesis penelitian ini adalah: Terdapat kemampuan komunikasi matematik yang lebih baik antara kelompok siswa yang mengikuti pembelajaran berbasis masalah terbuka, pembelajaran berbasis masalah terstruktur, dan pembelajaran konvensional.

\section{Kajian Pustaka}

\section{Komunikasi dalam \\ Pembelajaran Matematika}

Komunikasi merupakan kemampuan penting dalam pendidikan matematika. Komunikasi sebagai proses tidak hanya digunakan dalam sains, tetapi juga digunakan dalam keseluruhan kegiatan belajar matematika. Alasan mengapa pembelajaran matematika terfokus pada pengkomunikasian diungkapkan oleh Jacob (2002:378), yaitu (1) matematika pada dasarnya sebagai suatu bahasa kedua; (2) matematika dan belajar matematis dalam batinnya merupakan aktivitas sosial. Pendapat lainnya dikemukakan oleh Lindquist (NCTM, 1996:2), Jika kita sepakat bahwa matematika itu merupakan suatu bahasa dan bahasa tersebut sebagai bahasa terbaik dalam komunitasnya, maka mudah dipahami bahwa komunikasi merupakan esensi dari mengajar belajar, mengasses matematika.
Selain itu, ada kesesuaian antara persoalan matematika dengan persoalan dalam kehidupan sehari-hari. Jadi, jelaslah bahwa komunikasi dalam matematika merupakan kemampuan yang penting dan mendasar yang harus dimiliki pelaku dan pengguna matematika selama belajar mengajar.

2. Peranan Komunikasi Matematik dalam Memecahkan Masalah

Tanpa komunikasi dalam matematika kita akan memiliki sedikit keterangan, data, dan fakta tentang pemahaman siswa dalam melakukan proses dan aplikasi matematika. Karena itu, komunikasi dalam matematika dapat membantu siswa menginterpretasikan dan mengekspresikan pemahamannya tentang konsep dan proses matematika yang dipelajari. Komunikasi merupakan bagian yang esensial dalam matematika. Selain merupakan cara untuk berbagi idea dan pemahaman, melalui komunikasi idea-idea dapat menjadi objek refleksi, perbaikan, diskusi, dan penyempurnaan. Ketika siswa ditantang untuk berfikir dan bernalar tentang matematika dan mengkomunikasikan hasil pemikiran mereka secara lisan maupun tertulis, mereka diajak untuk belajar memperoleh pemahaman yang semakin jelas dan meyakinkan.

$$
\text { Menurut Sumarmo }
$$

kemampuan komunikasi matematika merupakan kemampuan yang dapat menyertakan dan memuat berbagai kesempatan untuk berkomunikasi dalam bentuk:

a. Merefleksikan benda-benda nyata, gambar, dan diagram ke dalam ide matematika;

b. Membuat model situasi atau persoalan menggunakan metode lisan, tertulis, konkrit, grafik, dan aljabar;

c. Menyatakan peristiwa sehari-hari dalam bahasa atau simbol matematika;

d. Mendengarkan, berdiskusi, dan menulis tentang matematika; 
e. Membaca dengan pemahaman suatu presentasi mateamtika tertulis;

f. Membuat konjektur, menyusun argumen, merumuskan definisi, dan generalisasi; dan

g. Menjelaskan dan membuat pertanyaan tentang matematika yang telah dipelajari.

\section{Pemecahan Masalah Terbuka}

Menurut Herman (2006: 50) dalam pemecahan masalah terbuka, masalah (problem) harus memiliki beberapa alternatif jawaban yang dapat diperoleh dari beberapa metode atau cara. Pusat perhatiannya bukanlah pada jawaban atau solusi dari masalah itu, namun lebih kepada cara bagaimana siswa sampai pada jawaban itu. Masalah yang tepat disuguhkan adalah masalah yang masih terjangkau kemampuan siswa namun tidak secara otomatis mereka mengetahui cara menyelesaikannya. Masalah haruslah tidak rutin, sehingga tidak familier bagi mereka namun menantang, dan bukan yang tidak dapat diselesaikan mereka.

Belajar melalui pemecahan masalah terbuka membantu siswa dalam mengembangkan pemahaman yang fleksibel, dalam arti dapat diadaptasi untuk situasi baru atau digunakan untuk mempelajari yang baru. Menurut Hiebert, Carpenter, Fennema, Fuson, Wearne, Murray, Oliver, \& Human (Herman, 2006:53) sesuatu yang dipelajari dengan pemahaman merupakan suatu kebutuhan dan keperluan di era perubahan global yang serba tak terduga ini. Selain itu belajar dengan pemahaman juga adalah mencapai intelektualitas matematika sebagai subjek. Berbeda dengan menghapal rumus-rumus atau aturan, memang siswa telah belajar sesuatu tapi mereka bukan belajar matematika. Belajar matematika haruslah masuk ke dalamnya dan melihat bagaimana sesuatu bekerja, bagaimana sesuatu berelasi dengan yang lainnya, dan mengapa berlaku seperti itu.

\section{Pemecahan Masalah Terstruktur}

$$
\text { Menurut Herman (2006:54) }
$$

mencermati kesulitan siswa dalam memecahkan masalah nonrutin terbuka (ill- structure problem) maka masalah seperti ini dapat disajikan dalam bentuk masalah terstruktur (well-structured problem). Dalam masalah terstruktur tentu saja sifat "keterbukaannya" bisa berkurang atau bahkan hilang karena berubah menjadi masalah tertutup, yaitu masalah yang tidak memiliki multicara penyelesaian atau tidak memiliki multijawaban yang benar.

5. Model Pembelajaran Berbasis Masalah (Problem-based learning)

Pembelajaran berbasis masalah (PBM) merupakan suatu strategi kognitif yang dimulai dengan menghadapkan siswa pada masalah keseharian yang nyata (authentic) atau masalah yang disimulasikan. Adapun pengertian tentang PBM menurut beberapa pandangan akan diuraikan sebagai berikut:

1). Stepien dan Gallagher (1993:1) mengemukakan,"Problem-based

Learning is a curriculum development and delivery system that recognizes the need to develop problem solving skills as well as the necessity of helping students to acquire necessary knowledge and skills".

2). Barrows dan Kelson (2001:1) menyatakan,

$P B L$ is both a curriculum and a process. The curriculum consist of carefully selected and designed problems that demand from the learner acquisition of critical knowledge, problem solving proficiency, self-directed learning strategies, and team participation skills. The process replicates the commonly used systemic approach to resolving problems or meeting challenges that are encountered in life and career.

Menurut Ram (1999:1) tahaptahap pembelajaran berbasis masalah terdiri dari lima tahap, seperti tampak pada Tabel 1 berikut: 
Tabel 1

Tahap-tahap Pembelajaran Berbasis Masalah

\begin{tabular}{|c|c|c|}
\hline Tahap & Indikator & Aktivitas/Kegiatan Siswa dan Guru \\
\hline 1 & Introduction & $\begin{array}{l}\text { - students are presented with a succinct problem } \\
\text { statement that gives them a well-defined role that } \\
\text { they can adopt. }\end{array}$ \\
\hline 2 & Inquiry & $\begin{array}{l}\text { - the facilitator guides the inquiry process so that } \\
\text { students elicit data about the problem, look for } \\
\text { additional information in the materials provided (the } \\
\text { inquiry materials), and write down the topics that } \\
\text { they need to look up (the learning issues). } \\
\text { - the facilitator demonstrates how to organize the } \\
\text { problem-solving process into distinct steps. } \\
\text { - the information generated in the discussion is } \\
\text { entered in one of four categories: Facts, Hypotheses } \\
\text { (Ideas), Learning Issues, and Action Plan. } \\
\text { - at the end of the first session, students commit to } \\
\text { one of the many hypotheses and select learning } \\
\text { issues that they will pursue independently. }\end{array}$ \\
\hline 3 & Self-derected study & $\begin{array}{l}\text { - having committed to a hypothesis and chosen } \\
\text { learning issues. } \\
\text { - students look up information from different } \\
\text { sources-with some initial guidance. }\end{array}$ \\
\hline 4 & $\begin{array}{l}\text { The revisiting the } \\
\text { hypotheses stage }\end{array}$ & $\begin{array}{l}\text { students evaluate the resources they used and share } \\
\text { information with their colleagues. they reconsider } \\
\text { their hypotheses with the benefit of the new } \\
\text { information they have gathered as they try to solve } \\
\text { the problem. }\end{array}$ \\
\hline 5 & The self-evaluation stage & $\begin{array}{l}\text { - students are asked to evaluate their efforts and their } \\
\text { groupmates" efforts as problem solvers, as self- } \\
\text { directed leamers, and as members of a group and to } \\
\text { discuss these evaluations with their group. }\end{array}$ \\
\hline
\end{tabular}

Menurut Herman (2006:60) perbedaan antara pembelajaran konvensional (biasa) dengan PBM adalah seperti tampak pada Tabel 2:

Tabel 2

Perbandingan Pembelajaran Konvensional dan PBM

\begin{tabular}{|c|c|c|}
\hline Komponen & Pembelajaran Konvensional & PBM \\
\hline Peran guru & $\begin{array}{l}\text { Sebagai ahli: } \\
\text { - Langsung memberilkankonsep } \\
\text { dan cara pengerjan (pro sectural) } \\
\text { - Menjadi sumber pengetahuan } \\
\text { utama } \\
\text { - Mengevaluasi siswa/menilai siswa }\end{array}$ & $\begin{array}{l}\text { Sebagai instruhtur: } \\
\text { - Memberikan menyajikanmasalah } \\
\text { - Memberi contoh, melatih dan } \\
\text { mengarahkan } \\
\text { - Terlibat dalam proses sebagai asisten } \\
\text { membantu siswa } \\
\text { - Mengevaluasi seluruhkomponen } \\
\text { pembelajaran }\end{array}$ \\
\hline Peran siswa & $\begin{array}{l}\text { Sebagai penerima: } \\
\text { - Lamban/tidak giat } \\
\text { - Tidak aktif }\end{array}$ & $\begin{array}{l}\text { Sebagai peserta: } \\
\text { - Aktif berinteraksi secara kooperatif } \\
\text { - Melakukanaktivitas dalam proses } \\
\text { pemecahanmasalah }\end{array}$ \\
\hline Aspek kognitif & $\begin{array}{l}\text { Siswa meniru pengetahuan yang telah } \\
\text { diterima dan menggungkannya }\end{array}$ & $\begin{array}{l}\text { Sis wa mengumpulkan dan membangun } \\
\text { pengetahuan untuk pemecahan masalah }\end{array}$ \\
\hline Metakognitif & $\begin{array}{l}\text { Siswa pasif } \\
\text { - Mempelajari keterampilan } \\
\text { menjadi tanggungjawab siswa }\end{array}$ & $\begin{array}{l}\text { Guru memberi contoh, melatih dan } \\
\text { mengarahkan sesuai dengan yang } \\
\text { dibutuhkan siswa } \\
\text { - Siswa mengembangkan strategi untuk } \\
\text { memperoleh s olusi danmengarahkan } \\
\text { cara belajarnya sendiri. }\end{array}$ \\
\hline
\end{tabular}




\section{Penilaian Kemampuan Komunikasi Matematik}

Menurut Iryanti (2004) salah satu jenis penilaian adalah penilaian kinerja atau penilaian unjuk kerja. Penilaian unjuk kerja memiliki kelebihan dapat mengungkap potensi siswa dalam memecahkan masalah, penalaran, dan komunikasi dalam bentuk tulisan maupun lisan. Danielson (1998:1) mendefinisikan penilaian unjuk kerja sebagai berikut,

Performance assessment means any assessment of student learning that requires the evaluation of student writing, products, or behavior. That is, it includes all assessment with the exeption of multiple choice, matching, truelfalse testing, or problems with a single correct answer.

\section{Rubrik}

Rubrik adalah pedoman penskoran penilaian unjuk kerja. Rubrik analitik adalah pedoman untuk menilai berdasarkan beberapa kriteria yang ditentukan. Dengan menggunakan rubrik ini dapat dianalisa kelemahan dan kelebihan seorang siswa terletak pada kriteria yang mana. Rubrik holistik adalah pedoman untuk menilai berdasarkan kesan keseluruhan atau kombinasi semua kriteria. Menurut Iryani (2004) rubrik yang diterapkan untuk SD dan SMP adalah rubrik analitik, sedangkan rubrik yang digunakan untuk SMA adalah rubrik holistik. Menurut Iryani, beberapa hal yang harus diperhatikan dalam membuat rubrik penilaian unjuk kerja adalah sebagai berikut: (1) Jenis kriteria, (2) Sub kriteria, (3) Skala penilaian, (4) Membagi skala untuk batasan memenuhi dan tidak memenuhi, (5) Sebutan untuk tiap tingkat, (6) Deskripsi untuk tingkat penampilan yang berbeda, dan Menghitung skor.

\section{Metode Penelitian}

\section{Desain Penelitian}

Dalam penelitian ini perlakuannya sebagai berikut :
1). Ada tiga kelompok siswa, yaitu kelompok yang model pembelajarannya menggunakan model pembelajaran berbasis masalah (PBM) terbuka, PBM terstruktur, dan Pembelajaran Konvensional.

2). Untuk mengetahui kemampuan komunikasi matematik siswa, maka siswa diberi tes awal dan tes akhir yang keduanya merupakan tes yang sama.

Menurut Ruseffendi (1998:44) desain penelitiannya adalah desain kelompok kontrol pretes-postes:
$\mathrm{A} \mathrm{OX} \mathrm{X}_{1} \mathrm{O}$
$\mathrm{A} \mathrm{OXX}_{2} \mathrm{O}$
$\mathrm{A} \mathrm{O}$$$
\mathrm{O}
$$

Keterangan :

$\mathrm{A}=$ Pengelompokkan secara acak menurut kelas

$\mathrm{O}=$ Pemberian tes awal/ Tes Akhir (Tes Kemampuan Komunikasi)

$\mathrm{X}_{1}=$ Model PBM terbuka

$\mathrm{X}_{2}=$ Model PBM terstruktur

\section{Subyek Populasi dan Sampel}

Subyek populasi penelitian ini adalah siswa SMP Negeri kategori sekolah kelompok tinggi di Kabupaten Garut.

Penelitian ini dilaksanakan pada siswa kelas VIII salah satu SMP Negeri di Kabupaten Garut. Sampel diambil secara acak, tanpa mengubah kelas yang ada. Pemilihan sampel dilakukan dengan cara menuliskan masing-masing kelas, dan model pembelajaran yang akan dilakukan pada sebuah kertas kemudian menggulungnya. Kemudian, dari kedua gulungan kertas tersebut masing-masing diambil secara acak. Dari pengambilan tersebut diperoleh sampel penelitiannya seperti pada Tabel 3:

Tabel 3. Sampel Penelitian

\begin{tabular}{|c|c|c|}
\hline Kelas Sampel & Model Pembelajaran & Nama Kelas \\
\hline VIII A & PBM terbuka & Eksperimen 1 \\
\hline VIII B & PBM terstruktur & Eksperimen 2 \\
\hline VIII C & Konvensional & Kontrol \\
\hline
\end{tabular}




\section{Variabel Penelitian}

Penelitian ini melibatkan dua jenis variabel: variabel bebas, yaitu Pembelajaran Berbasis Masalah (PBM) terbuka dan PBM terstruktur serta pembelajaran konvensional; variabel terikat, yaitu kemampuan komunikasi matematika siswa.

\section{Pengembangan Instrumen Penelitian}

Adapun pemberian skor tes komunikasi matematik menggunakan penskoran rubrik analitik, yaitu memberikan penilaian terhadap aspekaspek kemampuan komunikasi matematik.

Adapun rubrik penilaian tes komunikasi matematik adalah:

\begin{tabular}{|c|c|c|c|c|}
\hline \multirow{2}{*}{ Putra Finlas } & \multicolumn{3}{|c|}{ 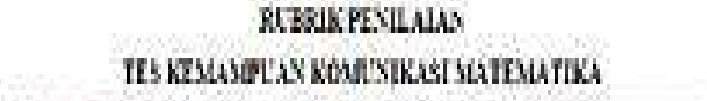 } & \\
\hline & 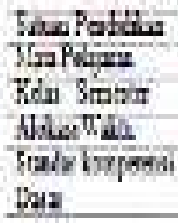 & 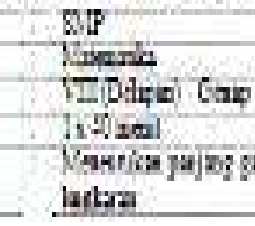 & Wangahing it & \\
\hline Thins & 1 & 7 & $T$ & T \\
\hline 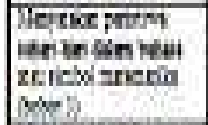 & 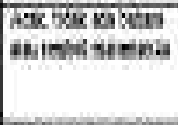 & 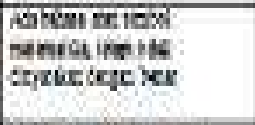 & 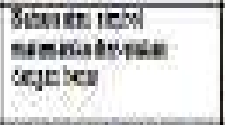 & 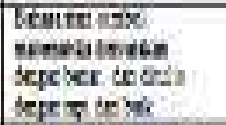 \\
\hline 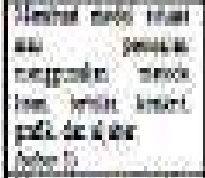 & 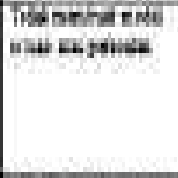 & 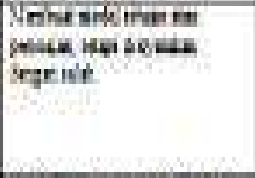 & 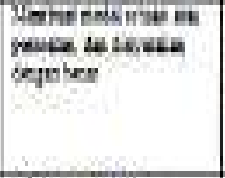 & 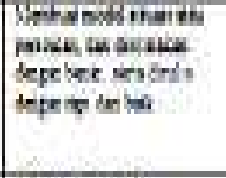 \\
\hline 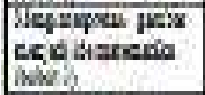 & 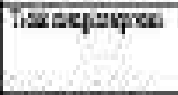 & 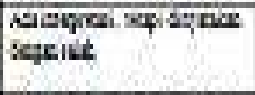 & $\begin{array}{l}\text { Adetprin in } \\
\text { Lrablaje teu }\end{array}$ & 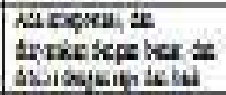 \\
\hline 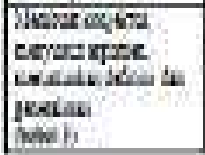 & 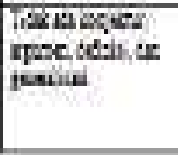 & 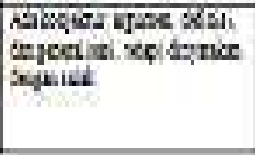 & 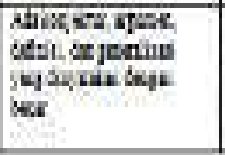 & 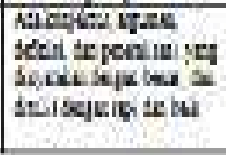 \\
\hline
\end{tabular}

\section{Analisa Data}

Analisis data hasil tes kemampuan komunikasi matematik siswa dilakukan secara kuantitatif. Uji statistik yang digunakan berdasarkan pemilihan uji statistik seperti pada Tabel 4: 
Tabel 4. Pemilihan Uji Statistik Univariat/Bivariat

\begin{tabular}{|c|c|c|c|c|c|}
\hline \multicolumn{6}{|c|}{ PEMILIHAN UJI STATIBNIK UNIVAAIAT / BIVAMIAT } \\
\hline \multirow[b]{2}{*}{$\begin{array}{c}\text { Tujuan } \\
\text { uji }\end{array}$} & \multirow[b]{2}{*}{$\begin{array}{l}\text { Jumiah } \\
\text { sampei / } \\
\text { Dasangan }\end{array}$} & \multirow{2}{*}{$\begin{array}{l}\text { Macam } \\
\text { sampel } \\
\text { (bobas i } \\
\text { berpasangen) }\end{array}$} & \multicolumn{3}{|c|}{ Jonis variabel } \\
\hline & & & $\begin{array}{c}\text { Rasioninuerval } \\
\text { pop. berdintribusi } \\
\text { netmal }\end{array}$ & $\begin{array}{l}\text { Ordinal } \\
\text { nanko-interval } \\
\text { distib, tak } \\
\text { poetweat }\end{array}$ & $\begin{array}{l}\text { Nominal } \\
\text { Thaleowik }\end{array}$ \\
\hline \multirow{4}{*}{$\begin{array}{l}\text { Koaryoua asi } \\
\text { ipesteda- } \\
\text { any }\end{array}$} & \multirow[t]{2}{*}{2} & $\begin{array}{c}\text { Debas } \\
\text { anderenideney }\end{array}$ & $\begin{array}{c}U_{F}: 2 \text { samper } \\
\text { bebos }\end{array}$ & 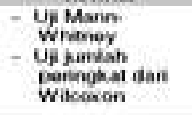 & 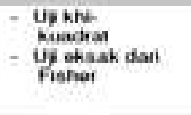 \\
\hline & & 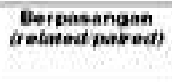 & $\begin{array}{l}\text { Uji } 1 \text { somedi } \\
\text { fetpasarosen }\end{array}$ & 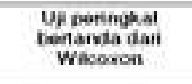 & $\begin{array}{l}\text { Uil MeNemai } \\
\text { Whateravi } \\
\text { dikotoriat; }\end{array}$ \\
\hline & \multirow[t]{2}{*}{$=2$} & $\begin{array}{c}\text { Debias } \\
\text { (indintermatent) }\end{array}$ & Anwa t arah & Uji Kniskali Wafte & Wikhi-kuadeal \\
\hline & & 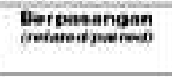 & $\begin{array}{c}\text { Answa w sialowek } \\
\text { yo same }\end{array}$ & Up Fivedman & 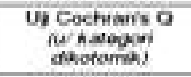 \\
\hline Kerelast & & & $\begin{array}{l}\text {. Koteiaei dan } \\
\text { Peanoni in } \\
\text { (Peogesi) }\end{array}$ & 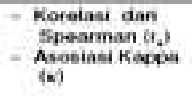 & $\begin{array}{l}\text { Koedicien } \\
\text { Kontingensi }(C) \\
\text { - Koetielen bhi }\end{array}$ \\
\hline
\end{tabular}

Adapun pengolahan data yang penulis lakukan, menggunakan program SPSS versi 10.0 adalah sebagai berikut:

1. Menguji normalitas data dengan menggunakan KolmogorofSmirnov; dengan kriteria jika nilai Sig $(p)>\alpha$, maka sebaran data berdistribusi normal.

2. Untuk mengetahui adanya perbedaan atau tidak mengenai kemampuan komunikasi matematik siswa, penulis menggunakan uji statistik non parametrik dalam hal ini uji Kruskall-Wallis, dengan kriteria: jika Sig $(p)<0,05$ maka terdapat perbedaan kemampuan antara ketiga kelompok.

\section{Hasil Penelitian}

Data yang diperoleh dan dianalisis dalam penelitian ini berupa nilai hasil pretest, postest dan skor gain pada aspek kemampuan komunikasi matematik siswa.

\section{Skor Pretest Kemampuan} Komunikasi Matematik Siswa Kelas Eksperimen 1, Eksperimen 2, dan Kelas Kontrol

\section{Tabel 5}

Statistik Deskintif Skor Pretest Kelas Eksperimen 1, Eksperimen 2, dan Kelas Kontrol

\begin{tabular}{|c|c|c|c|c|c|}
\hline \multirow{2}{*}{$\begin{array}{c}\text { Skor } \\
\text { Ideal }\end{array}$} & \multicolumn{5}{|c|}{ Kemampuan Komunikasi Matematik } \\
\cline { 2 - 6 } & $x_{\text {min }}$ & $x_{\text {muts }}$ & $\bar{x}$ & $\%$ & $s$ \\
\hline 48 & 12 & 30 & 18,54 & 38,63 & 6,45 \\
\hline 48 & 12 & 30 & 20,82 & 43,38 & 5,57 \\
\hline 48 & 12 & 18 & 12,68 & 26,42 & 1,44 \\
\hline
\end{tabular}

Untuk membuktikan bahwa skor pretest kelas eksperimen 1, eksperimen 2, dan kelas kontrol berbeda atau tidak secara signifikan, dilakukan analisis statistik pengujian perbedaan rerata tiga sampel, namun terlebih dahulu dilakukan uji normalitas. Dalam penelitian ini, untuk analisis statistik penulis mengggunakan program SPSS versi 10.0.

Uji normalitas yang penulis gunakan adalah uji Kolmogorof-Smirnov, dengan kriteria : jika nilai $\operatorname{Sig}(p)>\alpha$, maka sebaran data berdistribusi normal. Taraf signifikan pada pengujian ini adalah 0,05 . Hasil uji normalitas nilai pretest kemampuan komunikasi matematik dari ketiga kelompok sampel dapat dilihat pada Tabel 6. 
Tabel 6 Hasil Uji Nomalitas Nilai Pretest Kemampuan Komunikasi Matematik Kelas Eksperimen 1, Kelas Eksperimen 2, dan Kelas Kontrol |

\begin{tabular}{|c|c|c|c|c|}
\hline Kelas & $\begin{array}{c}\text { Kolmogorov- } \\
\text { Smimov Z }\end{array}$ & $\begin{array}{c}\text { Asymp. } \\
\text { Sig. }\end{array}$ & $\alpha$ & Kesimpulan \\
\hline Eksperimen 1 & 2,021 & 0,001 & 0,05 & Tidak Normal \\
\hline Eksperimen 2 & 1,470 & 0,027 & 0,05 & Tidak Normal \\
\hline Kontrol & 3,039 & 0,000 & 0,05 & Tidak Normal \\
\hline \multicolumn{5}{|c}{ Unengetahui adanya }
\end{tabular}

perbedaan atau tidak mengenai nilai pretest kemampuan komunikasi matematik dari ketiga kelompok sampel, digunakan uji statistik non parametrik dalam hal ini uji KruskallWallis. Teknik Kruskal-Wallis menguji hipotesis-nol bahwa $\mathrm{k}$ sampel berasal dari populasi sama atau populasipopulasi identik, dalam hal harga reratanya. (Siegel, 1997: 230). Kriteria pengujian $H_{0}$ adalah: terima $H_{0}$ jika Sig $(p)>\alpha$. Hasil Uji Kruskall-Wallis untuk nilai pretest kemampuan komunikasi dari ketiga kelompok sampel dapat dilihat pada Tabel 7.

Tabel 7 Hasil Uji Kruskall-Wallis Nilai Pretest Kemampuan Komun Matematik Kelas Eksperimen 1, Kelas Eksperimen 2, dan Kela Kontrol

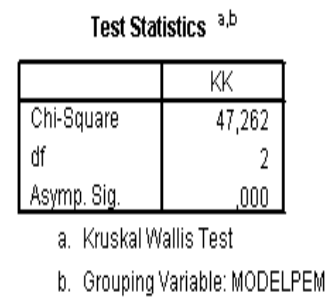

Dari Tabel 7 nilai Asymp.Sig. $=0,000$ $<\alpha=0,05$, karenanya tolak $H_{0}$, dimana $H_{0}=$ Tidak terdapat perbedaan yang signifikan kemampuan komunikasi matematik kelas eksperimen 1, kelas eksperimen 2, dan kelas kontrol. Sehingga dapat disimpulkan bahwa paling tidak ada sebuah yang berbeda secara signifikan antara kemampuan awal kemampuan komunikasi matematik kelas eksperimen 1, kelas eksperimen 2, dan kelas kontrol.

\section{Skor Postest Komunikasi Matematik Siswa Kelas Eksperimen 1, Eksperimen 2, dan Kelas Kontrol}

\author{
Tabel 8 \\ Statistik Deskniptif Skor Postest Kelas Eksperimen 1, Eksperimen 2, \\ dan Kelas Kontrol
}

\begin{tabular}{|c|c|c|c|c|c|c|}
\hline \multirow{2}{*}{ Kelas } & \multirow{2}{*}{$\begin{array}{c}\text { Skor } \\
\text { Ideal }\end{array}$} & \multicolumn{5}{|c|}{ Kemampuan Komunikasi Matematik } \\
\cline { 3 - 7 } & $x_{\min }$ & $x_{\text {met. }}$ & $\bar{x}$ & $\%$ & $\mathrm{~s}$ \\
\hline Eksp. 1 & 48 & 12 & 42 & 30,85 & 64,27 & 6,78 \\
\hline Eksp. 2 & 48 & 12 & 30 & 24,97 & 52,02 & 3,67 \\
\hline Kontrol & 48 & 12 & 36 & 27,98 & 58,29 & 6,01 \\
\hline
\end{tabular}

Untuk membuktikan bahwa kemampuan akhir dalam aspek komunikasi matematik kelas eksperimen 1, eksperimen 2, dan kelas kontrol berbeda atau tidak secara signifikan, dilakukan analisis statistik pengujian perbedaan rerata gain ternormalisasi tiga sampel, namun terlebih dahulu dilakukan uji normalitas. Penggunaan rerata gain ternormalisasi dalam aspek kemampuan komunikasi matematik dikarenakan terdapat perbedaan kemampuan awal dalam aspek komunikasi matematika dari ketiga kelompok sampel.

Uji normalitas yang penulis gunakan adalah uji Kolmogorof-Smirnov, dengan kriteria : jika nilai Sig $(\mathrm{p})>\alpha$, maka sebaran data berdistribusi normal. Taraf signifikan pada pengujian ini adalah 0,05 . Hasil uji normalitas gain ternormalisasi kemampuan komunikasi dari ketiga kelompok sampel dapat dilihat pada Tabel 9.

Tabel 9 Hasil Jji Nomalitas.VLai Gain Temomalisasi Kemmmpun KommikasiNatematik Kelas Eksperimen 1, Kelas Eksperimen 2, dan Kelas Kontrol

\begin{tabular}{|l|c|c|c|c|}
\hline Kelas & $\begin{array}{c}\text { Kolmogorov- } \\
\text { Smimov Z }\end{array}$ & Asymp. Sig. & $\alpha$ & Kesimpulan \\
\hline Eksperimen 1 & 1,544 & 0,017 & 0,05 & TidakNomal \\
\hline Eksperimen 2 & 0,787 & 0,565 & 0,05 & Nomal \\
\hline Kontrol & 0,962 & 0,314 & 0,05 & Nomal \\
\hline
\end{tabular}

Untuk mengetahui adanya perbedaan atau tidak mengenai nilai gain ternormalisasi kemampuan komunikasi matematik dari ketiga kelompok sampel, digunakan uji statistik non parametrik dalam hal ini uji Kruskall-Wallis. 
Kriteria pengujian perbedaan rerata tiga sampel adalah: terima $H_{0}$ jika $\operatorname{Sig}(\mathrm{p})$ $>\alpha$, di mana:

$H_{0}=$ Tidak terdapat perbedaan yang signifikan gain ternormalisasi kemampuan komunikasi matematika kelas eksperimen 1, kelas eksperimen 2, dan kelas kontrol.

$H_{1}=$ Paling tidak ada sebuah yang berbeda secara signifikan antara gain ternormalisasi kemampuan komunikasi matematika kelas eksperimen 1, kelas eksperimen 2, dan kelas kontrol.

Tabel 10 Hasil Uji Kruskall-Wallis Nilai Gain temormalisasi Kemampuar Komunikasi Matematik Kelas Eksperimen 1, Kelas Eksperimen 2, dan Kelas Kontrol

Test Statisticsa,b
\begin{tabular}{|l|r|}
\hline & \multicolumn{1}{|c|}{ KK } \\
\hline Chi-Square & 26,304 \\
df & 2 \\
Asymp. Sig. &, 000 \\
\hline
\end{tabular}
a. Kruskal Wallis Test
b. Grouping Variable: MODELPEM

Taraf signifikan pada pengujian ini adalah 0,05. Dari hasil pengujian diperoleh nilai Asymp.Sig. = $0,000<\alpha=0,05$, karenanya tolak $H_{0}$. Sehingga dapat disimpulkan bahwa paling tidak ada sebuah yang berbeda secara signifikan antara gain ternormalisasi kemampuan komunikasi matematika kelas eksperimen 1, kelas eksperimen 2, dan kelas kontrol.

\section{Menentukan Kemampuan Komunikasi Matematik yang Lebih Baik antara Siswa Kelas Eksperimen 1, Kelas Eksperimen 2, dan Kelas Kontrol}

Untuk menentukan manakah yang lebih baik antara kemampuan komunikasi matematik siswa pada kelas eksperimen 1, eksperimen 2, dan kelas kontrol ditinjau dari data secara keseluruhan maka digunakan uji perbedaan dua rerata antara dua kelompok sample seperti Tabel 11:

Tabel 11 Uji Perbedaan Dua Rerata Kemampuan Komunikasi Matematik antara Dua Kelompok Sampel

\begin{tabular}{|c|c|c|}
\hline Kelas yang Diuji & $\begin{array}{c}\text { Distribusi Data Gain } \\
\text { Temomalisasi }\end{array}$ & Uji yang Digunakan \\
\hline $\begin{array}{c}\text { Kelas Eksperimen 1, } \\
\text { Kelas Eksperimen 2 }\end{array}$ & $\begin{array}{c}\text { Tidak Nomal, } \\
\text { Nomal }\end{array}$ & UjiMann Whitney \\
\hline $\begin{array}{c}\text { Kelas Ekspenimen 1, } \\
\text { Kelas Kontrol }\end{array}$ & $\begin{array}{c}\text { Tidak Nomal, } \\
\text { Nomal }\end{array}$ & UjiMann Whitney \\
\hline $\begin{array}{c}\text { Kelas Ekspermen 2, } \\
\text { Kelas Kontrol }\end{array}$ & $\begin{array}{c}\text { Nomal, } \\
\text { Nomal } \\
\text { Kedua vanans Homogen }\end{array}$ & Ujit \\
\hline
\end{tabular}

Berdasarkan perhitungan mengguna-kan SPSS versi 10.0, diperoleh hasil seperti tersaji pada Tabel 12:

\begin{tabular}{|c|c|c|}
\hline Kelas yang Diuji & Hasil & Hnol \\
\hline $\begin{array}{l}\text { Kelas Eksperimen 1, } \\
\text { Kelas Eksperimen 2 }\end{array}$ & Terdapat Perbedaan & Ditolak \\
\hline $\begin{array}{l}\text { Kelas Eksperimen 1, } \\
\text { Kelas Kontrol }\end{array}$ & Tidak Terdapat Perbedaan & Ditenima \\
\hline $\begin{array}{c}\text { Kelas Eksperimen 2, } \\
\text { Kelas Kontrol }\end{array}$ & Terdapat Perbedaan & Ditolak \\
\hline
\end{tabular}

Berdasarkan Tabel 12, kemampuan komunikasi antara siswa pada kelas eksperimen 1 dan kelas eksperimen 2, antara kelas eksperimen 2 dan kelas kontrol, menunjukkan adanya perbedaan, sedangkan antara kelas eksperimen 1 dan kelas kontrol menunjukkan tidak adanya perbedaan. secara keseluruhan kemampuan komunikasi matematik siswa yang mengikuti pembelajaran berbasis masalah terbuka sama baiknya dengan siswa yang mengikuti pembelajaran konvensional. Kemampuan komunikasi matematik siswa yang mengikuti pembelajaran berbasis masalah terbuka dan pembelajaran konvensional lebih baik daripada siswa yang mengikuti pembelajaran berbasis masalah terstruktur.

4. Menentukan Peningkatan Kemampuan Komunikasi Komunikasi Matematik yang Lebih Baik antara Siswa Kelas Eksperimen 1, Kelas Eksperimen 2, dan Kelas Kontrol Ditinjau dari Kemampuan Awal

Peningkatan kemampuan komunikasi matematik dilihat berdasarkan skor gain ternormalisasi kemampuan komunikasi matematik siswa. Skor gain ternormalisasi kemampuan komunikasi matematik siswa adalah selisih skor postest dan pretest dibagi selisih skor ideal dan 
pretest baik kelas eksperimen 1, eksperimen 2, dan kelas kontrol. Berdasarkan pengolahan data terhadap skor postest dan pretest pada aspek yang akan diukur, yaitu aspek kemampuan komunikasi matematik, diperoleh diperoleh skor minimum $\left(x_{\text {min }}\right)$, skor maksimum $\left(x_{\text {maks }}\right)$, skor rerata $\bar{x}$, Kategori dan deviasi standar $(s)$.

Tabel13 Statistik Desknpptif Skor Gain Temomalisasi Kelas Ekspermen 1, Ekspermen 2 dan Kelas Kontrol

\begin{tabular}{|c|c|c|c|c|c|c|}
\hline \multirow[b]{2}{*}{ Kelas } & \multirow{2}{*}{$\begin{array}{l}\text { Sloor } \\
\text { Iddeal }\end{array}$} & \multicolumn{5}{|c|}{ Kemampuan Komunikasi Matematik } \\
\hline & & $x_{\text {in }}$ & $X_{\text {mati }}$ & $\bar{x}$ & Kate-gori & s \\
\hline Eksp. 1 & 1 & .057 & 0,83 & 0,37 & sedang & 0,33 \\
\hline Eksp. 2 & 1 & $.0,33$ & 0,5 & 0,12 & rendah & 0,31 \\
\hline Kontrol & 1 & 0,00 & 0,67 & 0,43 & sedarng & 0,17 \\
\hline
\end{tabular}

Dari Tabel 13 Peningkatan kemampuan komunikasi matematika kelas eksperimen 1 dan kelas kontrol mempunyai kategori sedang, sedangkan untuk kelas eksperimen 2 mempunyai kategori rendah. Hal ini menunjukkan bahwa peningkatan kemampuan komunikasi matematik pada kelas eksperimen 1 dan kelas kontrol menunjukkan peningkatan dengan kategori yang sama, dan lebih baik dari pada kelas eksperimen 2.

\section{Kesimpulan}

Peningkatan kemampuan komunikasi matematik siswa yang mengikuti pembelajaran berbasis masalah terbuka dan pembelajaran konvensional mempunyai peningkatan yang sama dengan kategori sedang. Peningkatan kemampuan komunikasi matematik siswa yang mengikuti pembelajaran berbasis masalah terbuka dan pembelajaran konvensional lebih baik daripada siswa yang mengikuti pembelajaran berbasis masalah terstrukutur dengan kategori rendah.

\section{Saran}

1. Bagi guru matematika, Pembelajaran Berbasis Masalah terbuka (PBM terbuka) dapat menjadi salah satu alternatif pembelajaran di kelas yang dinilai dapat meningkatkan kemampuan komunikasi matematik.

2. Bagi guru matematika, pembelajaran konvensional masih baik untuk dilakukan dalam pembelajaran di kelas, dan dinilai dapat meningkatkan kemampuan komunikasi matematik, jika soal-soal latihan yang diberikan tidak hanya soal rutin, tetapi juga diberikan soal-soal tidak rutin atau soal-soal pemecahan masalah.

\section{Daftar Pustaka}

Barrows, H. dan Kelson, A. (2001). Problem Based Learning (on line). Tersedia. http://www.meli.dist.maricopa.edu/pbl/info.ht ml. [4 Februari 2005]

Danielson, Charlote \& Marquez, Elizabeth. (1998). A Collection of Performance Task And Rubrics: High School Mathematics. Larchmont, NY: Eye On education, Inc.

Herman, T. (2006). Pembelajaran Berbasis Masalah untuk Meningkatkan Kemampuan Berpikir Matematis Tingkat Tinggi Siswa Sekolah Menengah Pertama (SMP). Disertasi pada PPS Universitas Pendidikan Indonesia, Bandung: Tidak Diterbitkan.

Jacob, C. (2002). "Matematika sebagai Komunikasi". Jurnal Matematika atau Pembelajarannya. (8). 378-382.

Mulyasa, E. (2003). Kurikulum Berbasis Kompetensi (Konsep Karakteristik Implementasi). Bandung: Rosdakarya.

NCTM. [National Council of Teachers of Mathematics]. (2000a). Principles and Standards for School Mathematics. Virginia: NCTM.

NCTM. [National Council of Teachers of Mathematics]. (2000b). Mathematics Assesment: A Practical Handbook for Grades 6-8. Reston, VA: NCTM.

Pugalee, D.A. (2001). Using Communication to Develop Students' Mathematical Litarcy. JRME. V6 January 2001. 
Purniati, T. (2003). Matematik Pembelajaran Geometri Berdasarkan Tahap-tahap Awal Van Hiele dalam Upaya Meningkatkan Kemampuan Komunikasi Siswa Sekolah Lanjutan Tingkat Pertama. Tesis pada PPS Universitas Pendidikan Indonesia, Bandung: Tidak Diterbitkan.

Ram, P. (1999). Problem-Based Learning in Undergraduate Education. Journal of Chemical Education Vol. 76 No. 8 Agustus 1999. JChem Ed. Chem.wisc.edu. (on line).[Tersedia]. http://www.jchemed.chem.wisc.ed u Links Journal JCE1999p1122. [Januari 2007]

Riedesel, C.A. (1990). Teaching Elementary School Mathematics. Boston: Allyn Bacon.
Rohaeti, E. E. (2003). Pembelajaran dengan Metode IMPROVE untuk Meningkatkan Pemahaman dan Kemampuan Komunikasi Matematik Siswa SLTP. Tesis pada PPS Universitas Pendidikan Indonesia, Bandung: Tidak diterbitkan.

Stepien, W.J., dan Gallagher, S.A. (1993). "Problem Based Learning: as Authentic as is Gets". "Edicational Leadership". (On Line). Tersedia: http://www.ascd.org/reading [4 Februari 2005].

Sumarmo, Utari. (2003). Pembelajaran Matematika untuk Mendukung Pelaksanaan Kurikulum Berbasis Kompetensi. Makalah Disajikan pada Pelatihan Guru Matematika di STKIP Siliwangi Ciamis. Bandung: Tidak Diterbitkan.

\section{Identitas Penulis:}

Drs. Deddy Sofyan, M.Pd. Dosen Kopertis Wil. IV dpk. STKIP Garut. S1 Pend. Matematika IKIP Bandung, lulus Tahun 1992. S2 Pend. Matematika SPS UPI, lulus tahun 2008. 